\title{
Impaired degranulation but enhanced cytokine production after FceRI stimulation of diacylglycerol kinase $\zeta$-deficient mast cells
}

\author{
Benjamin A. Olenchock, ${ }^{1}$ Rishu Guo, ${ }^{3}$ Michael A. Silverman, ${ }^{1}$ \\ Jennifer N. Wu, ${ }^{1}$ Jeffery H. Carpenter, ${ }^{3}$ Gary A. Koretzky, ${ }^{1,2}$ \\ and Xiao-Ping Zhong ${ }^{3,4}$
}

1The Signal Transduction Program, The Abramson Family Cancer Research Institute and ${ }^{2}$ The Department of Medicine,
University of Pennsylvania School of Medicine, Philadelphia, PA 19104
${ }^{3}$ Department of Pediatrics and ${ }^{4}$ Department of Immunology, Duke University Medical Center, Durham, NC 27710

Calcium and diacylglycerol are critical second messengers that together effect mast cell degranulation after allergen cross-linking of immunoglobulin (Ig)E-bound FceRI. Diacylglycerol kinase (DGK) $\zeta$ is a negative regulator of diacylglycerol-dependent signaling that acts by converting diacylglycerol to phosphatidic acid. We reported previously that DGK $\zeta^{-1-}$ mice have enhanced in vivo T cell function. Here, we demonstrate that these mice have diminished in vivo mast cell function, as revealed by impaired local anaphylactic responses. Concordantly, DGK $\zeta^{-1-}$ bone marrow-derived mast cells (BMMCs) demonstrate impaired degranulation after Fc£RI cross-linking, associated with diminished phospholipase $\mathrm{C}_{\gamma}$ activity, calcium flux, and protein kinase $\mathrm{C}-\boldsymbol{\beta}$ II membrane recruitment. In contrast, Ras-Erk signals and interleukin- 6 production are enhanced, both during $\lg E$ sensitization and after antigen cross-linking of FceRI. Our data demonstrate dissociation between cytokine production and degranulation in mast cells and reveal the importance of DGK activity during IgE sensitization for proper attenuation of FceRl signals.

\section{CORRESPONDENCE \\ Gary Koretzky: \\ koretzky@mail.med.upenn.edu \\ OR \\ Xiao-Ping Zhong: \\ zhong001@mc.duke.edu}

Abbreviations used: BMMC, bone marrow-derived cell; DAG, diacylglycerol; DGK, DAG kinase; $\mathrm{IP}_{3}$, inositol 1,4,5trisphosphate; LAT, linker for activated T cells; MAPK, mitogen-activated protein kinase; PA, phosphatidic acid; PCA, passive cutaneous anaphylaxis; PI5K, phosphatidylinositol 4-phosphate 5-kinase; $\mathrm{PIP}_{2}$, phosphatidylinositol 4,5bisphosphate; PKC, protein kinase C; PLC $\gamma$, phospholipase $\mathrm{C} \gamma$.
Mast cells play important roles in both innate and adaptive immune responses. They are central effector cells in immune responses to parasites and in the pathogenesis of diseases such as asthma and allergy $(1,2)$. The high affinity receptor for $\operatorname{IgE}$ (FceRI) is one of several cell surface receptors critical for mast cell development and function (3). FceRI binds to IgE in the absence of antigen and subsequent cross-linking of IgE-bound Fc $\varepsilon$ RI by cognate antigen induces a signaling cascade that leads to mast cell degranulation and cytokine secretion, which contribute to both chronic allergic inflammation and acute anaphylaxis. Understanding FceRI signaling and mast cell activation is critical to devising new therapies for mast cell-mediated diseases.

Recent studies have greatly improved our understanding of $F_{c} \varepsilon$ RI signaling. After Fc $\varepsilon$ RI engagement, the Src family members Lyn and

B.A. Olenchock and R. Guo contributed equally to this work. The online version of this article contains supplemental material.
Fyn and the tyrosine kinase Syk are activated $(4,5)$. These molecules in turn recruit and activate other kinases such as the Tec family kinase Btk (6), phospholipid modifying enzymes including phosphatidylinositol 4,5-bisphosphate 3-kinase (PI3K) (7), the GTPase-activating molecule Vav1 (8), and adaptor molecules such as linker for activated T cells (LAT) (9), nonT cell activation linker (NTAL/LAB) $(10,11)$, $\mathrm{SH} 2$ domain containing leukocyte phosphoprotein of $76 \mathrm{kD}$ (SLP-76) $(12,13)$, and Grb2associated binder protein 2 (Gab2) (14). The formation of a multimolecular signaling complex coordinates activation of various downstream signaling pathways necessary for mast cell effector functions. These pathways include phospholipase $\mathrm{C} \gamma$ (PLC $\gamma)(15,16)$, protein kinase C (PKC) isoforms $(17,18)$, and mitogen-activated protein kinases (MAPKs) (19). PLC $\gamma$ hydrolyzes the membrane phospholipid phosphatidylinositol 4,5-bisphosphate ( $\left.\mathrm{PIP}_{2}\right)$, leading to the generation of two important 
second messengers, diacylglycerol (DAG) and inositol 1,4,5trisphosphate $\left(\mathrm{IP}_{3}\right) . \mathrm{IP}_{3}$ binds to its receptor in the endoplasmic reticulum and induces $\mathrm{Ca}^{2+}$ release into the cytoplasm. DAG recruits to the membrane and activates PKC family members and RasGRPs, which are recently identified guanine nucleotide exchange factors for Ras and Rap (20). Synergistic action of multiple downstream signals, particularly $\mathrm{Ca}^{2+}$ and PKCs, are required to induce mast cell degranulation $(18,21,22)$. Activated PKCs and MAPKs together promote transcription of many proinflammatory genes, including cytokines (22-25).

Both in vitro and in vivo evidence suggest a critical role for DAG in the regulation of mast cell function after FceRI engagement. Treatment of mast cells with DAG analogues in the presence of a $\mathrm{Ca}^{2+}$ ionophore can mimic Fc\&RI engagement and induce mast cells to degranulate and release active mediators $(26,27)$. Mice lacking PLC $\gamma 2$, the enzyme that generates $\mathrm{IP}_{3}$ and $\mathrm{DAG}$, have diminished mast cell function $(28,29)$. Similarly, deficiency in DAG effector molecules alters mast cell function. Multiple PKCs are expressed in mast cells, and activation of both classical and novel isoforms of PKC is regulated by DAG $(18,30)$. Different PKCs have distinct functions in mast cells. $\mathrm{PKC} \beta^{-1-}$ mast cells demonstrate decreased IL-6 production and degranulation in response to FceRI engagement (22), whereas $\mathrm{PKC}^{-/-}$mast cells respond more vigorously to suboptimal FceRI stimulation with more sustained $\mathrm{Ca}^{2+}$ mobilization and increased degranulation compared with WT mast cells (31). Thus, proper balance of PKC $\beta$ and PKC $\delta$ activities appears important for mast cell function.

These observations suggest that DAG levels must be tightly controlled in mast cells. One mechanism for terminating DAG signaling is by phosphorylation catalyzed by the DAG kinase (DGK) family of enzymes. Phosphorylation of DAG by DGKs converts DAG to phosphatidic acid (PA), thus preventing DAG from activating PKCs and RasGRPs (20, 32-34). Additionally, PA itself is a second messenger, and DGK activity could regulate mast cell function by affecting PA accumulation. In vitro, PA is a potent activator of PLC and phosphatidylinositol 4-phosphate 5-kinase (PI5K), enzymes involved in $\mathrm{PIP}_{2}$ degradation and production (35-37). Therefore, through conversion of DAG into PA, DGK enzymes could regulate many aspects of inositol lipid metabolism and mast cell activation after FceRI engagement.

We recently described mice deficient in DGK $\zeta$ and demonstrated that $\mathrm{T}$ cells from these animals are hyperresponsive to TCR stimulation. DGK $\zeta^{-/-}$mice mount enhanced antiviral immune responses, indicating that DGK $\zeta$ is an important in vivo negative regulator of TCR signaling and $\mathrm{T}$ cell activation $(38,39)$. We show here that DGK also regulates immune receptor signaling in mast cells. To our surprise, in vivo mast cell function is impaired in DGK $\zeta^{-/-}$mice as indicated by diminished local anaphylactic responses. To explore the mechanism underlying this finding, we have studied DGK $\zeta^{-1-}$ bone marrow-derived mast cells (BMMCs). We demonstrate that FceRI-induced degranulation of $\mathrm{DGK} \zeta^{-/-} \mathrm{BMMCs}$ is diminished, correlating with impaired PLC $\gamma$ activation and PKCßII membrane translocation. Similar to what we have observed after TCR stimulation, however, FceRI-induced activation of the Ras-Erk signaling pathway is enhanced and DGK $\zeta^{-/-}$ BMMCs produce increased IL-6 during IgE sensitization and after antigen cross-linking of the FceRI. Moreover, mast cell survival after growth factor withdrawal is greatly increased by DGK $\zeta$ deficiency, correlating with maintained phosphorylation of Akt. These findings indicate that DGK $\zeta$ functions to maintain mast cell responsiveness to antigen stimulation during passive sensitization with $\operatorname{IgE}$ and demonstrate separation of cytokine production and degranulation after FceRI stimulation of mast cells.

\section{RESULTS}

\section{Mast cells develop in DGK $\zeta$-deficient mice}

We previously reported that DGK $\zeta$ plays an important role in $\mathrm{T}$ cell activation $(38,39)$. DGK $\zeta$ is also expressed in mast cells and, as in T cells, the $115-\mathrm{kD}$ isoform is prominent (Fig. $1 \mathrm{~A})$. There are also smaller species reactive with the antiDGK $\zeta$ antibody, which may be products of protein degradation, as mast cells are rich in granules containing proteases. Alternatively, these might represent products of alternate transcripts. Importantly, the three major species reactive with the DGK $\zeta$ antibody are all absent in BMMCs from targeted mice (Fig. 1 A). Mast cell development is unaffected by DGK $\zeta$ deficiency for the following reasons: the numbers of mast cells in ear, skin, stomach, and spleen are similar in WT and $\mathrm{DGK}^{-/-}$mice (Fig. $1 \mathrm{~B}$ and not depicted); electron microscopy did not reveal any differences in cell morphology or number of intracellular granules (not depicted); and KO mast cells express similar levels of c-Kit and FceRI on their surfaces (Fig. 1 C). Additionally, DGK $\zeta$ deficiency does not result in compensatory up-regulation of transcripts for related DGK isoforms (Fig. S1, available at http://www.jem. org/cgi/content/full/jem.20052424/DC1).

\section{Decreased passive cutaneous anaphylaxis in DGK $\zeta$-deficient mice}

DGK $\zeta^{-1-} \mathrm{T}$ cells have enhanced homeostatic proliferation and antiviral responses in vivo (39). To test the importance of DGK $\zeta$ in mast cell function, we assessed allergic responses by examining passive cutaneous anaphylaxis (PCA), an in vivo measure of FceRI-dependent mast cell function. Unexpectedly, DGK $\zeta^{-/-}$mice had significantly impaired localized anaphylactic responses (Fig. $2 \mathrm{~A}$ ).

To explore why DGK $\zeta^{-1-}$ mice demonstrate impaired PCA responses, we first compared Fc $\varepsilon$ RI-triggered degranulation in WT versus $\mathrm{DGK}^{-/-}$BMMCs by measuring $\beta$-hexosaminidase release (Fig. 2 B). Fc $\varepsilon$ RI-induced degranulation was significantly diminished in $\mathrm{DGK} \zeta^{-1-}$ BMMCs (Fig. 2 B). PMA plus ionomycin (Io) stimulation, however, resulted in similar degranulation in WT and $\mathrm{DGK} \zeta^{-/-}$ BMMCs, indicating that the ability to release granules and total granule content is unaffected by DGK $\zeta$ deficiency. 

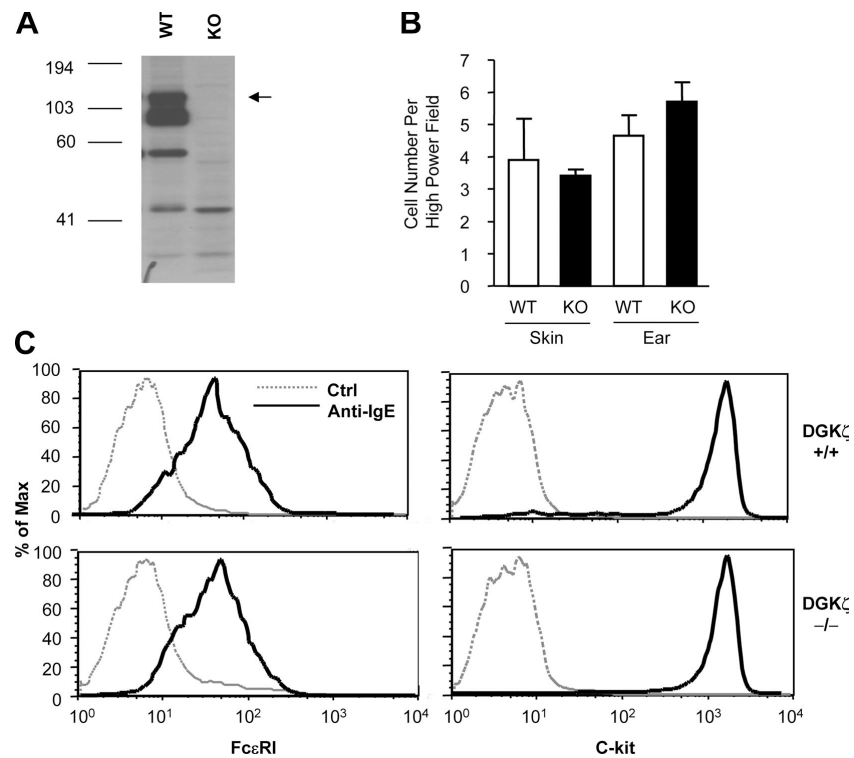

Figure 1. DGK $\zeta$ expression and surface expression of FceRI and

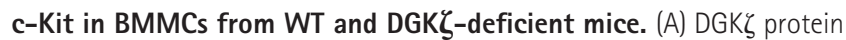
in cell lysates made from WT and DGK $\zeta$-deficient BMMCs was detected by Western blot analysis using an antibody specific for the carboxylterminus of DGK $\zeta$ (reference 71). The arrow indicates the 115-kD $\zeta 1$ isoform. (B) Mast cell distribution in the skin. Mast cells in the skin (back) and ears were stained with toluidine blue and were counted under a light microscope. Data shown are the means \pm standard error of the number of mast cells per high-power field $(10 \times 100)$. (C) FceRI and c-Kit expression on BMMCs. For FceRI expression, WT and DGK $\zeta$-deficient BMMCs were incubated with $1 \mu \mathrm{g} / \mathrm{ml}$ anti-DNP IgE for $4 \mathrm{~h}$ (solid line) and FceRl expression was detected by staining with a FITC-labeled anti-lgE secondary antibody. Cells that had not been incubated with lgE serve as a control (dotted line). For c-Kit expression, WT and DGK $\zeta$-deficient BMMCs were either stained with a PE-labeled control antibody (dotted line) or a PE-labeled anti-c-Kit antibody (solid line).

The impairment of FceRI-induced mast cell degranulation likely contributes to the decreased PCA responses in DGK $\zeta^{-/-}$mice.

Another consequence of FceRI engagement is the production of proinflammatory cytokines such as IL-6. IgE alone can induce a significant amount of IL-6 production in WT BMMCs (Fig. 2 C), which is consistent with previous reports (40). Cross-linking the receptor with antigen induces even more IL-6 production. Under both stimulation conditions, DGK $\zeta^{-\prime-}$ BMMCs produce approximately twofold more IL-6 than WT BMMCs. Therefore, DGK $\zeta$ deficiency impairs FceRI-induced degranulation, but increases cytokine production after IgE sensitization and after cross-linking of the receptor with antigen.

\section{Antigen stimulation of IgE-sensitized BMMCs}

Cross-linking of IgE-bound FceRI results in activation of a signaling network that coordinates mast cell effector functions. To investigate why DGK $\zeta^{-1-}$ BMMCs have impaired degranulation but enhanced cytokine production after Fc $\varepsilon$ RI

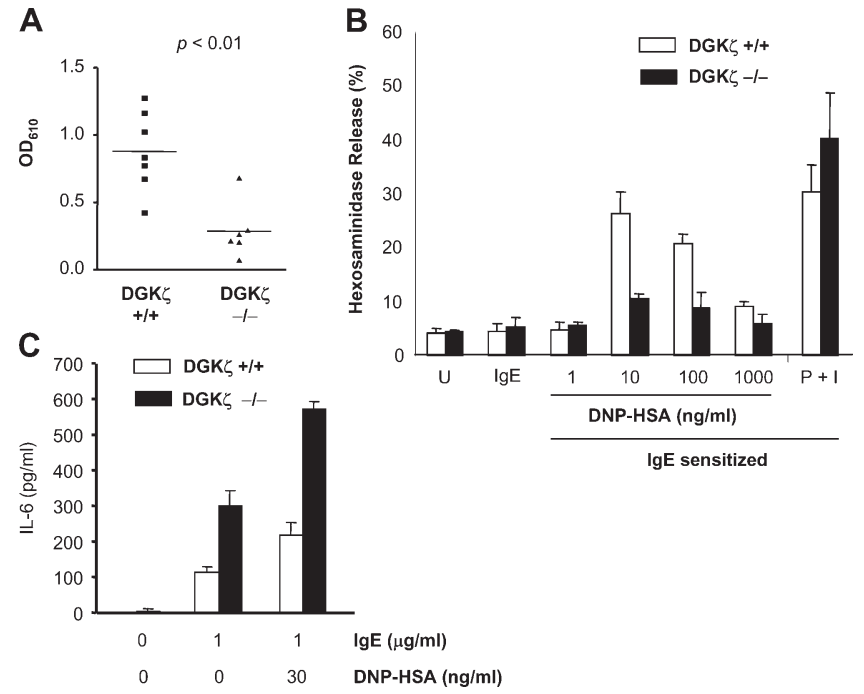

Figure 2. Decreased passive cutaneous anaphylaxis and FceRlinduced degranulation but increased IL- 6 production as the result of DGK $\zeta$ deficiency. (A) WT and DGK $\zeta^{-1-}$ mice were injected subcutaneously with $25 \mathrm{ng}$ lgE in $25 \mu \mathrm{l}$ PBS in the right ear and with $25 \mu \mathrm{l}$ PBS in the left ear. $24 \mathrm{~h}$ later, DNP-HSA and Evans blue dye were injected intravenously into the mice. 30 min after injection, tissue from the ears was collected, Evans blue was extracted, and the intensity of the dye was measured by absorption at $610 \mathrm{~nm}\left(\mathrm{OD}_{610}\right)$. Each data point is $\mathrm{OD}_{610}$ of $\mathrm{lg}$ E-injected ear minus the $\mathrm{OD}_{610}$ of PBS-injected ear from the same mouse. Data shown comprise three experiments. (B) Decreased FceRIinduced degranulation in DGK $\zeta^{-1-}$ BMMCs. IgE-sensitized WT and DGK $\zeta^{-1-}$ BMMCs were left unstimulated or were stimulated with various concentrations of DNP-HSA at $37^{\circ} \mathrm{C}$ for $60 \mathrm{~min}$. Cells were spun, and $\beta$-hexosaminidase activities in supernatants as well as in whole cell lysates of unstimulated BMMCs were measured. Data were calculated as percentage of $\beta$-hexosaminidase activity in the supernatant to the activity in the whole cell lysates of the same genotype. Means \pm standard error of triplicates are shown. Data are representative of three experiments.

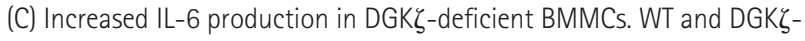
deficient BMMCs were left unstimulated, were stimulated with $1 \mu \mathrm{g} / \mathrm{ml}$ IgE overnight, or were sensitized with $1 \mu \mathrm{g} / \mathrm{ml} \operatorname{lgE}$ for $4 \mathrm{~h}$ and cross-linked with $30 \mathrm{ng} / \mathrm{ml}$ DNP-HSA overnight. IL-6 in the culture medium was measure by ELISA. Data shown are means \pm standard error of triplicates normalized to PMA/lo control and are representative of three experiments.

stimulation, we assessed how DGK $\zeta$ deficiency affects antigen-induced FceRI signaling in IgE-sensitized BMMCs. We first verified that DGK $\zeta$ phosphorylates DAG after antigen stimulation of BMMCs by measuring PA production. Addition of DNP-HSA to IgE-sensitized WT BMMCs results in robust PA accumulation beginning 5-10 min after stimulation (Fig. 3 A). As expected, antigen stimulation of DGK $\zeta^{-/-}$ BMMCs results in significantly less PA accumulation.

We next examined signaling pathways that have been implicated in cytokine production after FceRI ligation. Activation of the PI3K/Akt and Ras/Erk pathways is required for cytokine production $(23,25,41)$. Low dose stimulation of IgE-sensitized WT BMMCs with DNPHSA weakly activates Akt, but stimulation of DGK $\zeta^{-/-}$ BMMCs results in significantly increased Akt activation 


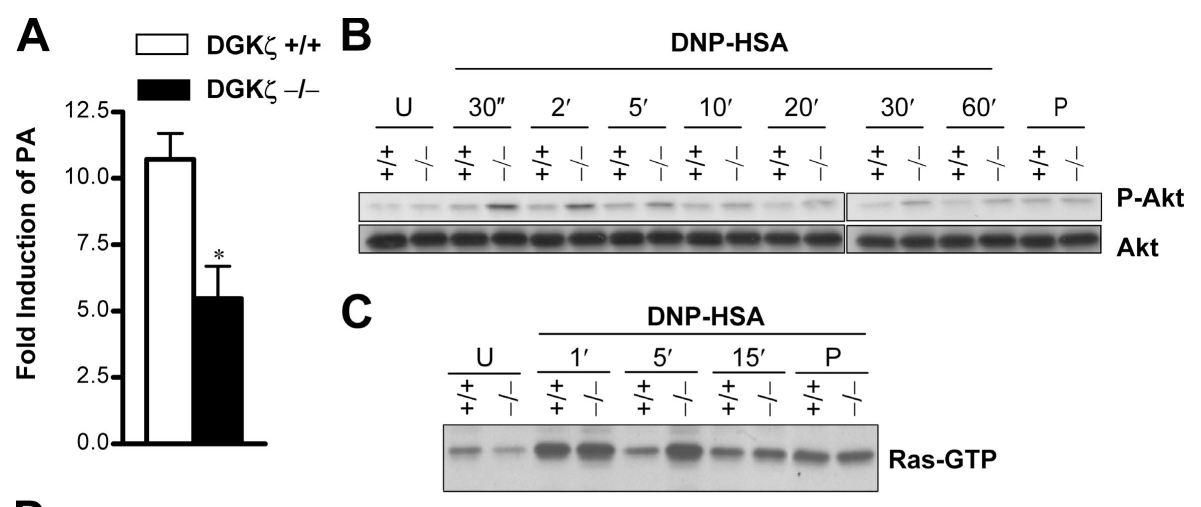

D DNP-HSA

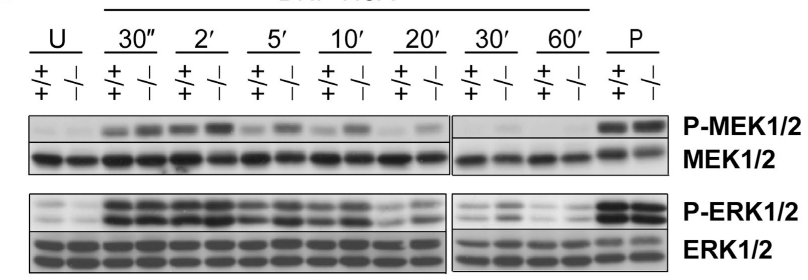

E
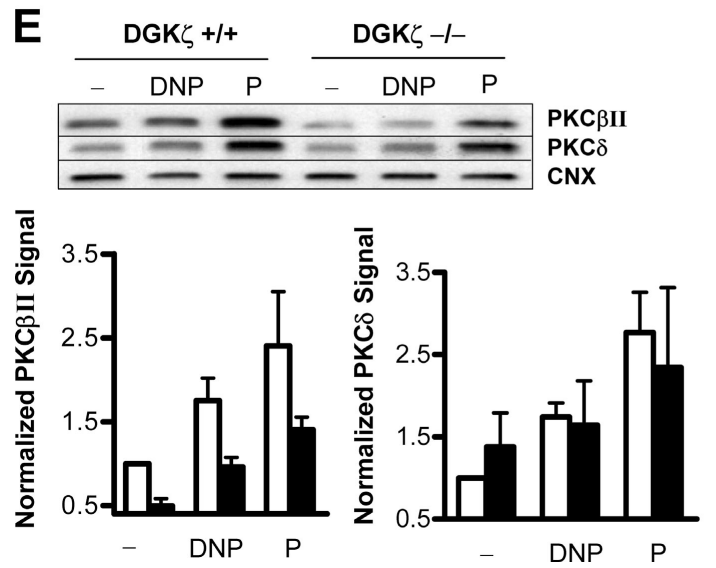

Figure 3. Antigen stimulation of IgE-sensitized BMMCs. (A) DGK deficiency impairs PA production by BMMCs after FceRI stimulation. BMMCs were sensitized for $4 \mathrm{~h}$ with lgE, labeled with ${ }^{32} \mathrm{P}$-orthorphosphate, and either left unstimulated or stimulated with $10 \mathrm{ng} / \mathrm{ml}$ DNP-HSA for 10 min. Lipids were extracted, separated by TLC, and quantified using a phosphorimager. PA, the product of DAG phosphorylation, was identified by comigration with a standard. Data are presented as fold-induction calculated by cpm of stimulated cells divided by cpm of unstimulated cells. Means \pm standard error of four experiments are shown; ${ }^{*}, P<0.05$. (B-D) WT and DGK $\zeta^{-1-}$ BMMCs were sensitized with IgE for $4 \mathrm{~h}$ and left unstimulated (U) or were stimulated either with $4 \mathrm{ng} / \mathrm{ml}$ of DNP-HSA for different times or with $100 \mathrm{ng} / \mathrm{ml}$ PMA (P) for $5 \mathrm{~min}$. (B) AKT phosphorylation was assessed by immunoblot analysis using an antibody specific for

(Fig. 3 B). FceRI activation of Ras is believed to be the result of Grb2-SOS activation $(42,43)$, but recent reports suggest that DAG might contribute to Ras activation through allosteric activation of the Ras guanine-nucleotide exchange factor RasGRP4 (44-46). As shown in Fig. $3 \mathrm{C}, \mathrm{Fc} \varepsilon \mathrm{RI}$-induced Ras activity is enhanced in DGK $\zeta^{-/-}$ BMMCs. Consistent with the increased Ras activation, we observed enhanced and prolonged Mek1/2 and Erk1/2 phosphorylated Ser473 of Akt. Total Akt is shown as a loading control. (C) Active Ras in lysates was measured by affinity precipitation using GSTRaf-RBD agarose beads followed by immunoblot analysis. (D) MEK $1 / 2$ and ERK $1 / 2$ activity was assessed by immunoblot analysis using phosphospecific antibodies. Total MEK1/2 and ERK1/2 serve as loading controls. (E) Membrane recruitment of PKC $\beta$ II is diminished in DGK $\zeta^{-1-}$ BMMCs. IgE-sensitized BMMCs were left unstimulated (-) or were stimulated with $50 \mathrm{ng} / \mathrm{ml}$ DNP-HSA (DNP) or PMA (P) for $10 \mathrm{~min}$. Triton-soluble membrane fractions were prepared and membrane translocation of PKC isoforms was determined by Western blot using antibodies to PKC $\beta I$, PKC $\delta$, and calnexin (CNX) as a loading control. One representative blot is shown and data from five (PKC $\beta I)$ or three (PKC $\delta$ ) experiments were quantified and normalized to CNX; combined data are represented graphically.

phosphorylation in DGK $\zeta^{-1-}$ BMMCs compared with WT BMMCs (Fig. 3 D). The effect of DGK $\zeta$ deficiency is selective, however, as FceRI-induced activation of the MAPKs p38 and Jnk is similar in WT and DGK $\zeta^{-/-}$ BMMCs (unpublished data). These data demonstrate that DGK $\zeta$ deficiency enhances FceRI-induced activation of Akt, Ras, and Erk1/2, likely contributing to enhanced cytokine production. 
A
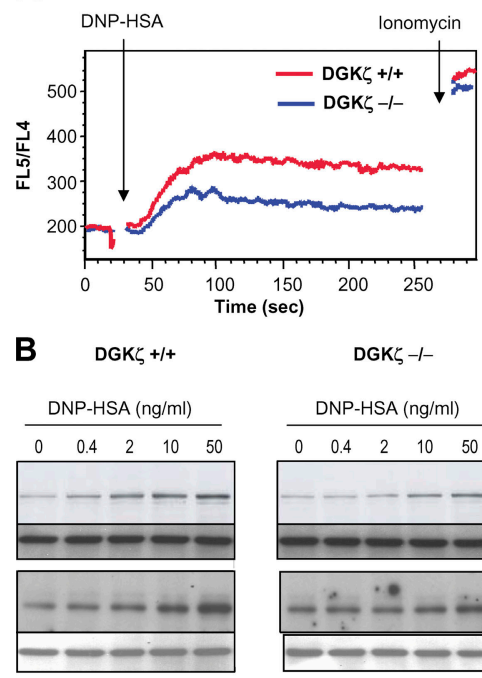

DGK $\zeta-I-$

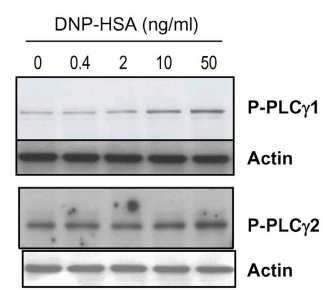

C

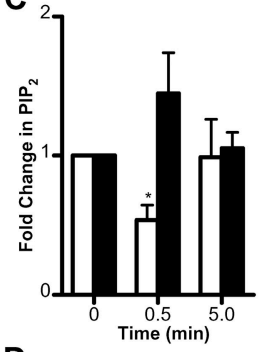

D

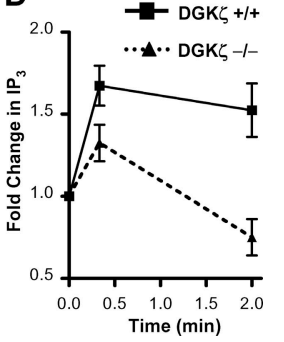

Figure 4. Decreased $\mathrm{Ca}^{2+}$ responses and $\mathrm{PLC} \gamma$ activity in $\mathrm{DGK \zeta}^{-/-}$ mast cells. WT and DGK $\zeta^{-1-}$ BMMCs were sensitized for $4 \mathrm{~h}$ with $\lg \mathrm{E}$ in cytokine-free media. (A) Deceased $\mathrm{Ca}^{2+}$ flux in $\mathrm{DGK}^{-1-}$ mast cells after FceRI stimulation. WT and DGK $\zeta^{-1-}$ BMMCs were loaded with Indo- 1 and stimulated with $100 \mathrm{ng} / \mathrm{ml}$ DNP-HSA to induce $\mathrm{Ca}^{2+}$ responses. $\mathrm{Ca}^{2+}$ flux was determined by flow cytometry based on the change of FL5/FL4 ratio. Data shown are representative of four experiments. (B) Decreased PLC $\gamma$ phosphorylation in DGK $\zeta^{-1-}$ BMMCs after Fc $\varepsilon$ RI stimulation. BMMCs were stimulated with different concentrations of DNP-HSA for $2 \mathrm{~min}$. PLC $\gamma$ phosphorylation was determined by Western blot with anti-phosphoPLC $\gamma 1$ and anti-phospho-PLC $\gamma 2$ antibodies. The blots were probed with an anti-actin antibody as a loading control. (C) Decreased $\mathrm{PIP}_{2}$ hydrolysis in $\mathrm{DGK \zeta}^{-1-}$ BMMCs. Cells were labeled with ${ }^{32} \mathrm{P}$-orthophosphate and stimulated for the indicated amounts of time with $10 \mathrm{ng} / \mathrm{ml}$ DNP-HSA; lipids were analyzed as in Fig. 3. $\mathrm{PIP}_{2}$ was identified by comigration with a standard. Data are means \pm standard error of four different experiments.

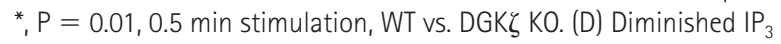
generation in DGK $\zeta^{-1-}$ BMMCs. Cells were left unstimulated or were stimulated with $10 \mathrm{ng} / \mathrm{ml}$ DNP-HSA for $20 \mathrm{~s}$ or $2 \mathrm{~min}$ and lysed using perchloric acid, and $\mathrm{IP}_{3}$ was measured.

Activation of PKC family members by DAG and $\mathrm{Ca}^{2+}$ coordinates mast cell degranulation after FceRI stimulation $(22,47)$. As expected, antigen cross-linking induces membrane recruitment of PKC $\beta I$ and PKC $\delta$ in WT BMMCs (Fig. 3 E). However, we find that membrane recruitment of PKC $\beta I$ is clearly diminished in DGK $\zeta^{-/}$BMMCs, whereas PKC $\delta$ recruitment is preserved. Unstimulated IgE-sensitized DGK $\zeta^{-\prime-}$ BMMCs also demonstrate diminished levels of membrane-associated PKC $\beta I I$ but normal PKC $\delta$ levels. Moreover, treatment with the DAG analogue PMA, which is not a DGK substrate and should be unaffected by DGK deficiency, results in impaired movement of PKC $\beta I I$ to the membrane in DGK $\zeta^{-1-}$ BMMCs but normal movement of PKC $\delta$ (Fig. 3 E, representative blot and graphical summary of replicates). The block in PKC $\beta I I$ recruitment was not the result of diminished protein levels, however, as total levels of PKC $\beta I$ and PKC $\delta$ in whole cell lysates were not decreased in DGK $\zeta^{-1-}$ BMMCs as compared with WT BMMCs

(Fig. S2, available at http://www.jem.org/cgi/content/full/ jem.20052424/DC1). These data provide a likely mechanism for the impaired degranulation we observe in $\mathrm{DGK} \zeta^{-/-}$ BMMCs, as Fce RI cross-linking results in less recruitment of a positive regulator (PKC $\beta I I)$ of mast cell degranulation, but appropriate recruitment of a negative regulator of mast cell degranulation (PKC $\delta$ ). The data also suggest that DGK $\zeta$ is essential for FceRI activity in addition to its effect on DAG levels, as PMA and PMA/Io (unpublished data) fail to restore PKCßII recruitment in DGK $\zeta^{-/-}$BMMCs.

\section{Calcium response and PLC $\gamma$ activity in DGK $\zeta^{-1-}$ BMMCs}

The diminished membrane recruitment of the $\mathrm{Ca}^{2+}$-dependent PKC $\beta I I$ along with the preserved movement of the $\mathrm{Ca}^{2+}-$ independent PKC $\delta$ led us to question whether DGK $\zeta$ deficiency affects FceRI-induced $\mathrm{Ca}^{2+}$ flux. Compared with WT BMMCs, DGK $\zeta^{-\prime-}$ BMMCs have a significantly diminished $\mathrm{Ca}^{2+}$ response after FceRI stimulation by antigen (Fig. 4 A). Consistent with the decreased $\mathrm{Ca}^{2+}$ response, phosphorylation of PLC $\gamma 1$ and PLC $\gamma 2$ after stimulation of the FceRI was decreased in DGK $\zeta^{-1-}$ BMMCs (Fig. 4 B). As tyrosine phosphorylation of PLC $\gamma$ does not always correlate with its enzymatic activity (48), we analyzed PLC activity by assessing metabolism of the

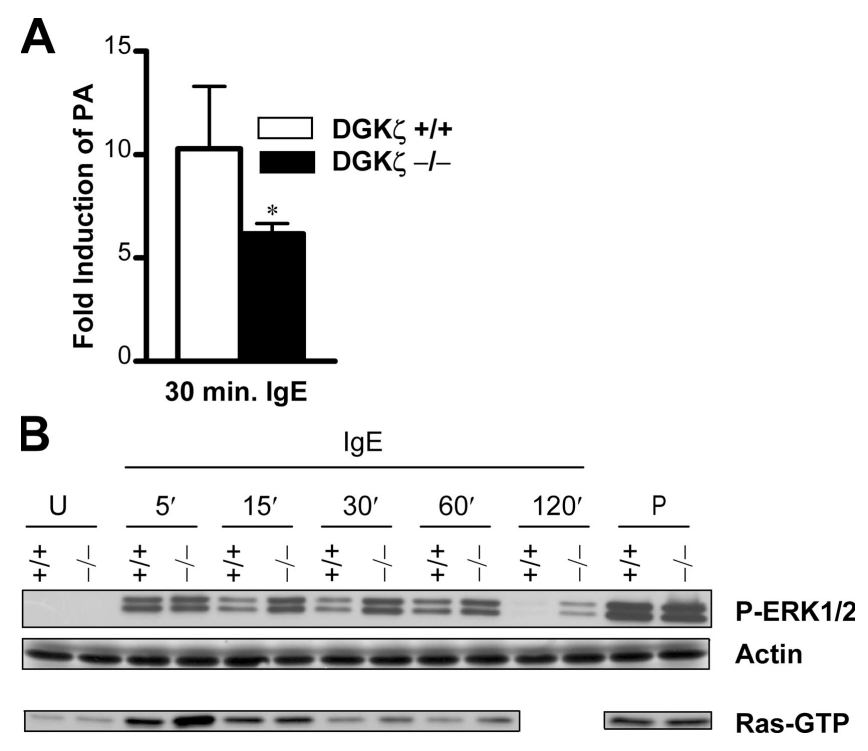

Figure 5. IgE stimulation in the absence of antigen cross-linking results in enhanced signaling in $\mathrm{DGK} \zeta^{-1-}$ BMMCs. BMMCs were rested in media without cytokines for at least $4 \mathrm{~h}$ and rested for $1 \mathrm{~h}$ in Tyrode's buffer before stimulation. (A) Impaired PA production in DGK $\zeta^{-1-}$ BMMCs. Cells were labeled with ${ }^{32} \mathrm{P}$-orthophosphate for $1 \mathrm{~h}$ and stimulated with $1 \mu \mathrm{g} / \mathrm{ml} \mathrm{lgE}$ for $30 \mathrm{~min}$. Lipids were extracted and PA production was quantified as in Fig. 3. Means \pm standard error of five experiments are shown. * $\mathrm{P}<0.05$. (B) Enhanced Ras/ERK activation in DGK $\zeta^{-1-}$ BMMCs. BMMCs were stimulated with $1 \mu \mathrm{g} / \mathrm{ml} \lg$ E for various amounts of time or with $100 \mathrm{ng} / \mathrm{ml}$ PMA for $5 \mathrm{~min}$. Active Ras and ERK1/2 phosphorylation were assessed as in Fig. 3. For the Ras blot, a space is included before the PMA lanes to designate that these samples were run on a separate gel. 
PLC substrate $\mathrm{PIP}_{2}$ and production of $\mathrm{IP}_{3}$. After receptor cross-linking in WT BMMCs, $\mathrm{PIP}_{2}$ levels quickly decrease (Fig. $4 \mathrm{C}$ ), and $\mathrm{IP}_{3}$ levels increase (Fig. $4 \mathrm{D}$ ) as a result of PLC activity. Upon stimulation of DGK $\zeta^{-/-}$BMMCs, we do not observe a decrease but rather a slight increase in $\mathrm{PIP}_{2}$ levels (Fig. $4 \mathrm{C}$ ), and $\mathrm{IP}_{3}$ generation is impaired (Fig. $4 \mathrm{D}$ ). These data provide compelling evidence that DGK $\zeta$ deficiency impairs activation of PLC $\gamma$ after antigen stimulation of IgE-sensitized mast cells.

\section{IgE signaling and function in the absence of antigen}

IgE sensitization of DGK $\zeta^{-/-}$BMMCs leads to increased cytokine production and impaired PKC $\beta I I$ recruitment to the membrane, so we therefore examined how $\mathrm{IgE}$ alone signaling and function is altered in DGK $\zeta$ deficiency. IgE binding to FceRI induces a large increase in PA in WT BMMCs (Fig. 5 A). DGK $\zeta^{-/-}$BMMCs, in contrast, have a significant impairment in PA accumulation during $\operatorname{IgE}$ sensitization. DAG-dependent signaling is also enhanced in DGK $\zeta^{-/-}$ BMMCs during $\operatorname{IgE}$ sensitization, as Ras and Erk1/2 activity is enhanced (Fig. $5 \mathrm{~B}$ ).

IgE binding to the FceRI signals mast cell survival through up-regulation of antiapoptotic proteins (40, 49-52), and ex vivo mast cell survival and expansion requires IL-3 $(53,54)$. In the presence of IL-3, both WT and DGK $\zeta^{-/-}$ mast cells survive and expand similarly (unpublished data). When IL-3 is withdrawn, WT BMMCs undergo apoptosis as expected (Fig. 6 A). Surprisingly, DGK $\zeta^{-/-}$BMMCs have greatly enhanced survival in the absence of IL-3. IgE enhances survival in both WT and DGK $\zeta^{-/-}$BMMCs, but because survival in the absence of cytokines is so much greater in the DGK $\zeta^{-/-}$BMMCs, the IgE survival effect is less marked (Fig. 6, A and B).

Akt regulates cell survival and is activated by $\operatorname{IgE}$ binding to FceRI (40). Akt is phosphorylated in WT BMMCs grown in cytokine-replete media, and this activation decreases after withdrawal of cytokines (Fig. $6 \mathrm{C}$ ). DGK $\zeta^{-/-}$BMMCs, in contrast, have enhanced Akt activity during growth in cytokine-replete media and maintain Akt activity after cytokine removal (Fig. 6 C). As cytokines stimulate inositol metabolism, including $\mathrm{PIP}_{2}$ hydrolysis by PLC $\gamma$ and phosphorylation by $\mathrm{PI} 3 \mathrm{~K}(55,56)$, it is likely that $\mathrm{DGK} \zeta$ regulates signals generated through cytokine receptors in addition to its role in FceRI signaling. Future work will explore the biochemical basis of this observation.

\section{DISCUSSION}

We have studied mice that lack a key enzyme involved in DAG metabolism, DGK $\zeta$, to address the consequences of dysregulated DAG accumulation after immune receptor signaling. We demonstrated recently that DGK $\zeta$ functions as a key negative regulator of TCR signaling and T cell activation $(38,39)$. We show here that DGK $\zeta$ plays an important and unexpected role in regulating signal transduction from the FceRI in mast cells. DGK $\zeta^{-/-}$BMMCs manifest decreased PA production, enhanced activation of the Ras-Mek-Erk

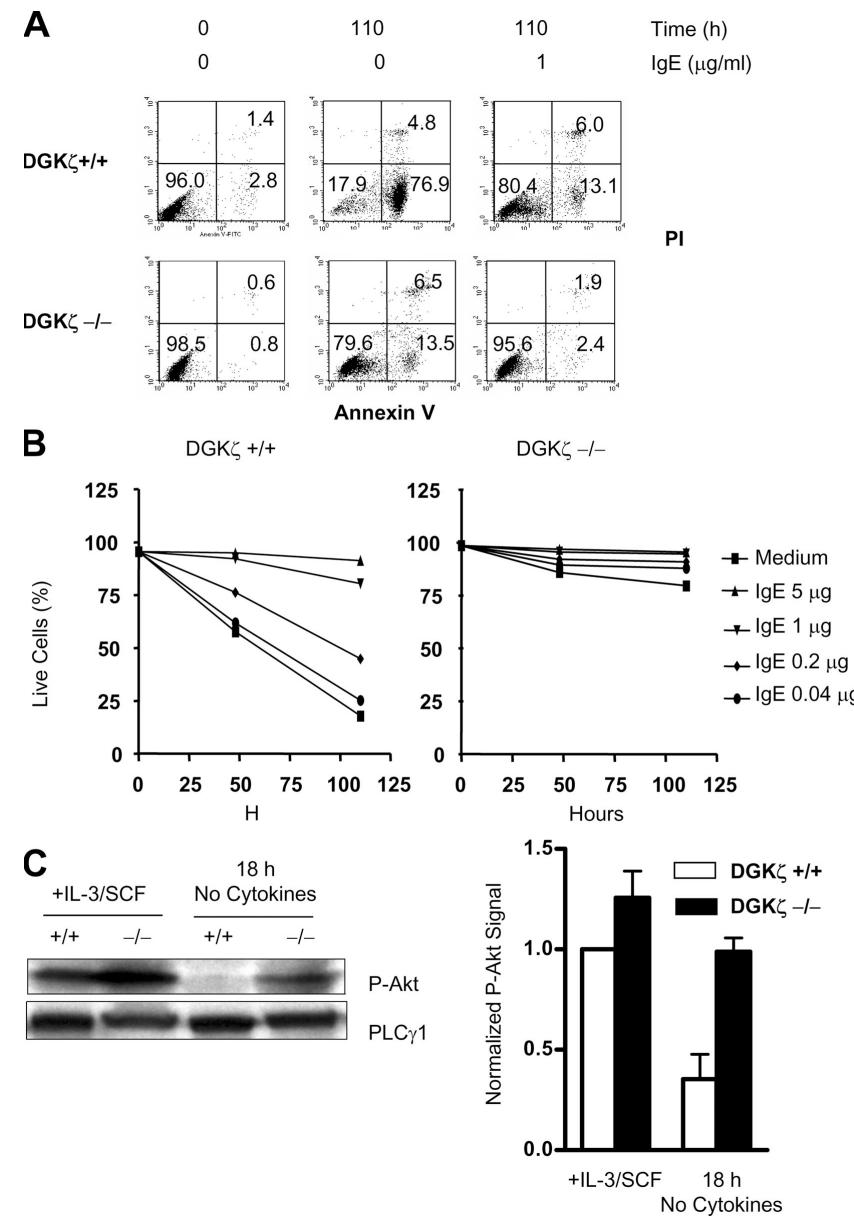

Figure 6. Enhanced survival of DGK $\zeta^{-/-}$BMMCs after IL-3 withdrawal. WT and DGK $\zeta^{-1-}$ BMMCs were cultured in media without cytokines in the presence of different concentrations of IgE for 48 or $110 \mathrm{~h}$. Survival of BMMCs was determined by staining with FITC-annexin $\mathrm{V}$ and $\mathrm{PI}$ and analyzed by flow cytometry. (A) Representative dot-plots. (B) Percentage of live cells (Annexin- $V$ and PI negative) in a full time course and at a range of concentrations of IgE. Data shown are representative of three experiments. (C) Akt phosphorylation during growth in cytokinereplete media (+IL3/SCF) and after $18 \mathrm{~h}$ cytokine withdrawal (18 h, no cytokines) was assessed by immunoblot analysis. One representative blot is shown and data from three independent experiments were quantified, normalized to PLC $\gamma 1$ signal, and represented graphically for comparison. P-AKT signal in WT cells grown in cytokine-replete media was arbitrarily set to 1 .

signaling pathway, increased Akt phosphorylation, prolonged survival after cytokine deprivation, and enhanced production of IL-6 as compared with WT BMMCs. Surprisingly, IgEmediated PCA responses are significantly decreased in DGK $\zeta^{-/-}$mice, concordant with impairment of receptorinduced PLC $\gamma$ activity and degranulation in $\mathrm{DGK} \zeta^{-/-}$ BMMCs. We demonstrate that signals generated by $\operatorname{IgE}$ in the absence of antigen cross-linking are enhanced in DGK $\zeta^{-/-}$ BMMCs. These data demonstrate that DGK $\zeta$ is important for inactivation of DAG-mediated signaling pathways in mast cells and that DGK $\zeta$ also plays a critical role in maintaining 
FceRI responsiveness to antigen cross-linking. In addition, we demonstrate a novel FceRI signaling alteration in DGK $\zeta^{-/-}$BMMCs, in that receptor engagement results in poor PLC $\gamma$ activity and degranulation but augmented cytokine production.

The observation that DGK $\zeta$ deficiency impairs PLC $\gamma$ function after FceRI stimulation of mast cells was unexpected, as DGK $\zeta$ was predicted to function downstream of PLC $\gamma$. It is possible that enhanced DAG-dependent signaling during $\operatorname{IgE}$ sensitization of $\mathrm{DGK} \zeta^{-/-}$BMMCs promotes feedback inhibition of PLC $\gamma$ and $\mathrm{Ca}^{2+}$ responses upon antigen cross-linking of the FceRI. Short pretreatment of mast cells with phorbol esters results in feedback inhibition of PLC $\gamma$ that is mediated by PKC $\alpha$ and PKC $\varepsilon$ (57-59). Prolonged administration of phorbol esters, in contrast, downregulates PKC isoforms and potentiates PLC activity upon antigen stimulation (59). We do not see changes in PKC protein levels in $\mathrm{DGK} \zeta^{-/-}$BMMCs, and we report impaired PLC activity. PKC feedback inhibition might be indirect as well, as PKC $\beta$ can induce serine-phosphorylation of Btk at an inhibitory site, dampening Btk activation in mast cells (60). Btk phosphorylates and activates PLC $\gamma$ after FceRI stimulation, so feedback inhibition of Btk could contribute to diminished PLC $\gamma$ activity (61). Alternatively, enhanced Erk activation in DGK $\zeta^{-/-}$BMMCs could inhibit PLC $\gamma$ association with LAT, as has been observed in T cells after TCR engagement (62). However, we have not observed an obvious decrease in PLC $\gamma 2$-LAT association in DGK $\zeta^{-\prime-}$ BMMCs after antigen cross-linking of the FceRI (unpublished data).

Alternatively, diminished PLC $\gamma$ activity and PKCßII membrane recruitment might be a direct consequence of DGK $\zeta$ deficiency. Although DGK activity terminates DAG signaling, it also creates PA $(32,33,63)$. PA is a potent activator of PLC $\gamma$ enzymatic activity in vitro (35). In addition, a recent report suggests that DGK $\zeta$, through production of PA, may increase intracellular $\mathrm{PIP}_{2}$ by activation of PI5K I $\alpha$ (37). Thus, DGK $\zeta$ deficiency could lead to decreased PI5K activity, diminishing levels of the PLC substrate $\mathrm{PIP}_{2}$. Our $\mathrm{PIP}_{2}$ measurements did not reveal any differences in ${ }^{32} \mathrm{P}$ incorporation into $\mathrm{PIP}_{2}$ in $\mathrm{IgE}$-sensitized BMMCs (unpublished data), but more direct measures of $\mathrm{PIP}_{2}$ mass should be performed to ensure that steady state levels of ${ }^{32} \mathrm{P}-$ labeled $\mathrm{PIP}_{2}$ reflect total mass. The importance of diminished PA production to the phenotype of DGK $\zeta^{-1-}$ BMMCs is particularly difficult to assess, as alternative pathways to generate PA exist. These pathways include the hydrolysis of phosphatidylcholine mediated by phospholipase $\mathrm{D}$ and the acylation of lyso-PA by lyso-PA acyltransferases (63). phospholipase D-derived PA has been reported to regulate diverse cellular processes, particularly in vesicle transportation and exocytosis $(64,65)$. It is possible that PA generated by DGK $\zeta$ performs a similar function to promote mast cell degranulation.

It is intriguing that membrane recruitment of PKC $\beta I$ is diminished in unstimulated IgE-sensitized $\mathrm{DGK} \zeta^{-1-}$
BMMCs and that PKC $\beta I I$ recruitment is not restored with PMA treatment. PMA is a DAG analogue and is not subject to phosphorylation by DGK, so we predict that if DGK $\zeta$ acts only by regulating DAG levels, PMA treatment should restore PKCßII membrane recruitment. It is possible that DGK $\zeta$ has adaptor functions in addition to its role in lipid metabolism, perhaps by participating in a complex with PKC $\beta I I$ or Btk directly $(37,66)$. Future work will explore this interesting observation.

We have been unable to directly measure an FceRIinduced change in DAG mass in WT or DGK $\zeta^{-\prime-}$ mast cells using standard biochemical approaches (unpublished data). The likely explanation is that the receptor-induced pool of DAG is a small fraction of the total cellular pool because DAG is important for other aspects of cell biology. We are currently developing imaging approaches to measure DAG localization using a fluorescently labeled DAG probe (67). We also will develop HPLC/MS/MS techniques to quantify particular DAG subspecies, which may be more markedly regulated than total cellular DAG (68). These approaches will allow us to measure dynamic changes in DAG localization after FceRI stimulation as well as assess in vivo substrate specificity of DGK $\zeta$.

The increased Akt phosphorylation in DGK $\zeta^{-/-}$BMMCs stimulated through cytokine or FceRs is intriguing. It is possible that increased Akt activity is a consequence of greater $\mathrm{PIP}_{3}$ production in $\mathrm{DGK} \zeta^{-/-}$BMMCs, and preliminary data support this hypothesis. Decreased PA production in DGK $\zeta^{-1-}$ BMMCs might increase PI3K activity, as PA has been reported to inhibit this enzyme in vitro (69). Also, perhaps decreased PLC $\gamma$ activity in DGK $\zeta^{-/-}$BMMCs increases the local concentration of $\mathrm{PIP}_{2}$ available as substrate for PI3K (66). The interrelation among different PI metabolites is complex and understanding the exact lipid alterations will require further study.

Our current studies of DGK $\zeta$ in mast cells reveal important roles for this enzyme in regulating FceRI signaling. DGK $\zeta$ is not only essential for terminating DAG activity but also appears to be critical for maintaining optimal FceRI responsiveness to antigen cross-linking. A more complete understanding of the importance of DGK activity to mast cell function requires analysis of other DGK family members. Ongoing biochemical and genetic studies are addressing this question.

\section{MATERIALS AND METHODS}

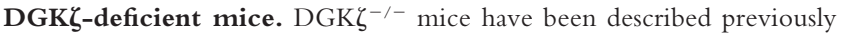
(39) and were housed in pathogen-free facilities at the University of Pennsylvania and Duke University. All experiments using animals were performed in accordance with regulations of the Institutional Animal Care and Use Committee of the University of Pennsylvania and Duke University.

Microscopic analysis of mast cells. Skin samples from the back of the trunk and the ears were collected from killed WT and DGK $\zeta^{-/-}$mice. Tissues were fixed and mounted in paraffin according to standard histological procedures. Paraffin sections were stained with toluidine blue and mast cells in tissues were evaluated by microscopy. In each tissue, mast cells were counted in 10 contiguous high-power fields $(10 \times 100)$. 
BMMCs. BM cells from tibias and femurs from WT and DGK $\zeta^{-/-}$mice were harvested and incubated with Isocove's medium (Mediatech, Inc.) supplemented with 15\% FBS (Hyclone), $100 \mathrm{U} / \mathrm{ml}$ penicillin $\mathrm{G}, 100 \mathrm{U} / \mathrm{ml}$ streptomycin, and $292 \mu \mathrm{g} / \mathrm{ml}$ of L-glutamine, $10 \mathrm{mM}$ Hepes ( $\mathrm{pH} 7.4$ ), $0.1 \mathrm{mM}$ nonessential amino acid, $1 \mathrm{mM}$ sodium pyruvate, and $50 \mu \mathrm{M}$ 2-mercaptoethanol (IMDM-15) with IL-3-conditioned medium for $2 \mathrm{wk}$ and further expanded for an additional 2-8 wk with the supplement of SCFconditioned medium made from cell lines engineered to produce these cytokines (70).

Flow cytometry. BMMCs were analyzed directly or after 4-h sensitization with $1 \mu \mathrm{g} / \mathrm{ml} \mathrm{IgE}$. Cells were stained with fluorescently labeled antibodies in 5\% FBS in PBS and were analyzed on a FACSCaliber (Becton Dickinson) with CELLQuest software. Antibodies used were PE-conjugated c-Kit and FITC-conjugated anti-IgE (BD Biosciences). To measure cell survival after cytokine withdrawal, cells were stimulated in IMDM-15 without cytokine at a concentration of $10^{6} \mathrm{cell} / \mathrm{s} / \mathrm{ml}$ in a 96-well plate with different concentrations of anti-DNP-IgE $(0,0.04,0.2,1$, or $5 \mu \mathrm{g} / \mathrm{ml}$; Sigma-Aldrich). After 48 or $110 \mathrm{~h}$ incubation, cells were stained with propidium iodide and annexin V-FITC (BD Biosciences) and were analyzed by flow cytometry.

Measurement of PA and PIP $_{2}$. BMMCs were sensitized at $37^{\circ} \mathrm{C}$ for $4 \mathrm{~h}$ in $1 \mu \mathrm{g} / \mathrm{ml} \mathrm{IgE}$ in IMDM-15 without IL-3 or SCF. Cells were harvested and rested in Tyrode's buffer (10 mM Hepes, pH 7.4, $130 \mathrm{mM} \mathrm{NaCl}, 1 \mathrm{mM}$ $\mathrm{MgCl}_{2}, 5 \mathrm{mM} \mathrm{KCl}, 1.4 \mathrm{mM} \mathrm{CaCl}_{2}, 5.6 \mathrm{mM}$ glucose, and $1 \mathrm{mg} / \mathrm{ml}$ bovine serum albumin) for $1 \mathrm{~h}$ at $37^{\circ} \mathrm{C} .{ }^{32} \mathrm{P}$-phosphoric acid (MP Biomedicals) was added to a concentration of $0.25 \mathrm{mCi} / \mathrm{ml}$. Cells were left unstimulated or were stimulated with $10 \mathrm{ng} / \mathrm{ml}$ DNP-HSA. Stimulation was terminated by addition of 0.1 volume of ice-cold $2 \mathrm{M} \mathrm{HCl}$ and transfer of cells to ice for $10 \mathrm{~min}$. Lipids were extracted with $3 \mathrm{ml}$ of 2:1 methanol:chloroform and phases were separated by addition of $2 \mathrm{ml} 1 \mathrm{~N} \mathrm{NaCl}$ and $2 \mathrm{ml}$ of chloroform. Lipid phase was washed $1 \times$ with $3 \mathrm{ml}$ of upper phase buffer (upper phase of 10:10:9 chloroform:methanol:1 $\mathrm{M} \mathrm{NaCl}$ ), dried under nitrogen, and separated by thin-layer chromatography using a basic solvent (9:7:2 chloroform: methanol: $\left.4 \mathrm{M} \mathrm{NH}_{4} \mathrm{OH}\right)$. PA and $\mathrm{PIP}_{2}$ were identified by comigration with standards (Sigma-Aldrich) and quantified using a phosphorimager.

Measurement of $\mathbf{I P}_{3}$. IgE-sensitized BMMCs were rested for $1 \mathrm{~h}$ in Tyrode's buffer, then left unstimulated or stimulated for $20 \mathrm{~s}$ or $2 \mathrm{~min}$ with $10 \mathrm{ng} / \mathrm{ml}$ DNP-HSA. Stimulations were terminated by addition of $0.2 \mathrm{vol}$ $20 \%$ perchloric acid for $20 \mathrm{~min}$ on ice. Proteins were sedimented and supernatants were neutralized to $\mathrm{pH} 7.5$ by titration of $1.5 \mathrm{M} \mathrm{KOH} 60 \mathrm{mM}$ Hepes containing universal indicator dye (Sigma-Aldrich). $\mathrm{KClO}_{4}$ was precipitated by centrifugation and $\mathrm{IP}_{3}$ was measured in supernatants by radioreceptor assay according to the manufacturer's protocol (PerkinElmer).

Western blot analysis. For DGK $\zeta$ expression, BMMCs were lysed in 1\% NP-40 lysis buffer (1\% NP-40, $150 \mathrm{mM} \mathrm{NaCl}, 50 \mathrm{mM}$ Tris, $\mathrm{pH}$ 7.4) with protease inhibitors. Proteins were resolved by SDS-PAGE, transferred to Trans-Blot Nitrocellulose membrane (Bio-Rad Laboratories), and probed with an anti-DGK $\zeta$ antibody for DGK $\zeta$ expression (71). To analyze Ras, Erk, Mek1/2, Jnk, and PLC $\gamma 1 / 2$ activation, IgE-sensitized BMMCs were resuspended in Tyrode's buffer. Cells were left unstimulated or stimulated with DNP-HSA for different times or PMA $(100 \mathrm{ng} / \mathrm{ml})$ for $5 \mathrm{~min}$. For $\mathrm{IgE}$ alone activation of Ras and Erk, cells were not sensitized, but rather were stimulated with $1 \mu \mathrm{g} / \mathrm{ml} \operatorname{IgE}$ or PMA. Phosphorylation of these proteins was determined by Western blot with antiphospho-specific antibodies for Erk1/2, Mek1/2, Jnk, Akt, and PLC $\gamma 1$ and PLC $\gamma 2$ (Cell Signal Technology). Membranes were stripped and reprobed with antibodies to Erk, Mek1, Jnk, Akt, and actin for loading controls. Activated Ras in cell lysates was determined by GST-Raf-RBD "pull-down" assay as described previously (38).

PKC membrane localization. BMMCs were sensitized for $4 \mathrm{~h}$ with $1 \mu \mathrm{g} / \mathrm{ml} \operatorname{IgE}$ in IMDM-15 without cytokines and rested for $1 \mathrm{~h}$ at $37^{\circ} \mathrm{C}$ in
Tyrode's buffer. Cells were stimulated with $50 \mathrm{ng} / \mathrm{ml}$ DNP-HSA or $100 \mathrm{ng} / \mathrm{ml} \mathrm{PMA}$ for $10 \mathrm{~min}$, and membrane fractions were isolated as described previously (72). Protein concentration in Triton soluble fraction was quantified using a bicinchonic acid assay (Pierce Chemical Co.) before PAGE analysis. Western blots were probed with antibodies to PKC $\delta$ (Cell Signal Technology), PKCßII (Santa Cruz Biotechnology, Inc.), and calnexin (Stressgen Bioreagents).

Detection of IL-6 production. Measurement of IL-6 production by BMMCs was performed as described with modifications (13). BMMCs were rested overnight in IMDM-15 plus IL-3. For the unstimulated condition, cells were resuspended in IMDM-10 at $2.5 \times 10^{5}$ cells $/ \mathrm{ml} .200 \mu \mathrm{l}$ cells were seeded in each well of a 96-well plate in triplicate. For FceRI stimulation, cells were washed and sensitized with $1 \mu \mathrm{g} / \mathrm{ml}$ anti-DNP IgE in IMDM-10 at $10^{7}$ cells $/ \mathrm{ml}$ for $4 \mathrm{~h}$, pelleted, washed once with IMDM-10, and resuspended at $5 \times 10^{5}$ cells $/ \mathrm{ml}$ in IMDM-10. $100 \mu \mathrm{l}$ aliquots of cells were placed into wells of a 96 -well plate, followed by addition of $100 \mu \mathrm{l}$ of IMDM-10 with $2 \mu \mathrm{g} / \mathrm{ml}$ of anti-DNP-IgE, with $60 \mathrm{ng} / \mathrm{ml}$ DNP-HSA, or with $40 \mathrm{ng} / \mathrm{ml}$ PMA and $200 \mathrm{ng} / \mathrm{ml}$ Io. Cells were incubated at $37^{\circ} \mathrm{C}$ with $5 \% \mathrm{CO}_{2}$ for $24 \mathrm{~h}$ and IL-6 in supernatants was measured using a murine IL-6 ELISA kit (Pierce Chemical Co.). Data are normalized to PMA/Io control.

$\boldsymbol{\beta}$-hexosaminidase release assay. Hexosaminidase release assay was performed as described previously with modification (13). BMMCs grown in IMDM-15 supplemented with IL-3 were stimulated with $\operatorname{IgE}$ at $37^{\circ} \mathrm{C}$ for $1 \mathrm{~h}$ to assess $\operatorname{IgE}$-induced degranulation or were sensitized with $1 \mu \mathrm{g} / \mathrm{ml} \operatorname{IgE}$ for $4 \mathrm{~h}$ and left unstimulated or stimulated with $10 \mathrm{ng} / \mathrm{ml}$ of DNP-HSA or PMA plus Io at $37^{\circ} \mathrm{C}$ for $1 \mathrm{~h}$. $\beta$-Hexosaminidase activities in the medium and in whole cell lysates were determined using p-nitro-phenyl- $N$-acetyl$\beta$-D-glucosamide as the substrate.

Passive cutaneous anaphylaxis assay. The passive cutaneous anaphylaxis assay was performed according to published protocols (73). Mice were anesthetized by intraperitoneal injection of $300 \mu \mathrm{l}$ of $2.5 \% 2,2,2-$ tribromoethanol in tert-amyl alcohol/PBS (1/40; Sigma-Aldrich), followed by subcutaneous injection of $25 \mathrm{ng} \operatorname{IgE}$ in $25 \mu \mathrm{l}$ PBS in the right ear and $25 \mu \mathrm{lBS}$ in the left ear. $24 \mathrm{~h}$ later, mice were anesthetized and $200 \mu \mathrm{l}$ antigen (100 $\mu \mathrm{g}$ DNP-HSA, 1\% Evans blue in PBS) was injected intravenously via the retroorbital sinus. 30 min after the injection, mice were killed and both ears were removed. Ears were incubated in $200 \mu \mathrm{l}$ formamide at $55^{\circ} \mathrm{C}$ for $48 \mathrm{~h}$ to extract the dye. Tissue debris was removed by centrifugation and the intensities of the dye were measured by absorption at $610 \mathrm{~nm}$. The data are calculated as $\mathrm{OD}_{610}$ of the IgE-injected ear minus the $\mathrm{OD}_{610}$ of the PBSinjected ear from the same mouse.

Calcium flux. BMMCs were sensitized with $1 \mu \mathrm{g} / \mathrm{mL} \operatorname{IgE}$ for $4 \mathrm{~h}$; resuspended at $10^{7}$ cells $/ \mathrm{ml}$ in Tyrode's buffer containing $3 \mu \mathrm{g} / \mathrm{ml}$ Indo-1 (Invitrogen) and $4 \mathrm{mM}$ probencid; and incubated for $30 \mathrm{~min}$ at $37^{\circ} \mathrm{C}$. Cells were washed twice with Tyrode's buffer and resuspended at $2 \times 10^{7}$ cells $/ \mathrm{ml}$. $40 \mu 1$ of cells was added into $460 \mu$ l of prewarmed Tyrode's buffer to measure $\mathrm{Ca}^{2+}$ responses by flow cytometry (BD-LSR; Becton Dickinson). After collection of the baseline ratio of FL5 to FL4, $10 \mu \mathrm{l}$ of $5 \mu \mathrm{g} / \mathrm{ml}$ DNP-HSA was added to stimulate cells. Calcium flux was assessed as the ratio of FL5 to FL4 fluorescence.

Online supplemental material. For measurement of DGK transcript levels, RNA was isolated from WT and DGK $\zeta^{-1-}$ BMMCs by TRIzol extraction (Invitrogen) and cDNA generated by reverse transcriptions (CLONTECH Laboratories, Inc.). Transcripts were quantified by SYBR green real-time PCR using the following primers: DGK $\alpha$ : 5'-GATGCAGGCACCCTGTACAAT-3', 5'-GGACCCATAAGCATAGGCATCT-3'; DGKס:5'-GGGACCTCAAGGACCTTGGT-3', 5' -TCAGCTCCTTGATCCCACAAA; and DGKı: 5'-TTCCCCAGGGCACTCTCA-3', 5'-CAGACGTTGCATCTAGGAAGCA-3'. No products were amplified from 
a no reverse transcriptase control sample (unpublished data). Transcripts were normalized to GAPDH signal (5'-GAAGGTACGGAGTCAACGGATTT-3', $5^{\prime}$-GAATTTGACCATGGGTGGAAT-3') using the $\Delta \Delta$ Ct method. For measurement of total cellular protein levels of PKC $\beta I$ and PKC $\delta$, WT and DGK $\zeta^{-1-}$ BMMCs were left unstimulated for $4 \mathrm{~h}$ in cytokine-free media with or without IgE $(1 \mu \mathrm{g} / \mathrm{ml})$. Cells were lysed in 1\% NP-40 lysis buffer with protease inhibitors, proteins were resolved by SDS-PAGE, and Western blots were probed with antibodies to PKC $\beta I I$ or PKC $\delta$. Blots were stripped and reprobed for actin as a loading control. Online supplemental material is available at http://www.jem.org/cgi/content/full/jem.20052424/DC1

We thank J. Stadanlick for help in preparation of the manuscript; M. Jordan for help in the $\mathrm{Ca}^{++}$experiment; S. Prescott and M. Topham for providing the anti-DGKל antibody; E. Myers and E. Hainey for technical assistance; and Drs. O.-C. Yu, H.-W. Yu, and Y. Wang for assistance in histological analysis.

This work was supported by the National Institutes of Health (G.A. Koretzky and X.-P. Zhong), from the Sandler Program for Asthma Research (G.A. Koretzky), and from the National Cancer Institute (B.A. Olenchock).

The authors have no conflicting financial interests.

\section{Submitted: 5 December 2005}

Accepted: 23 April 2006

\section{REFERENCES}

1. Benoist, C., and D. Mathis. 2002. Mast cells in autoimmune disease. Nature. 420:875-878.

2. Wedemeyer, J., M. Tsai, and S.J. Galli. 2000. Roles of mast cells and basophils in innate and acquired immunity. Curr. Opin. Immunol. 12:624-631.

3. Kinet, J.P. 1999. The high-affinity $\operatorname{IgE}$ receptor (FceRI): from physiology to pathology. Annu. Rev. Immunol. 17:931-972.

4. Zhang, J., E. Berenstein, R. Evans, and R. Siraganian. 1996. Transfection of Syk protein tyrosine kinase reconstitutes high affinity $\operatorname{IgE}$ receptormediated degranulation in a Syk-negative variant of rat basophilic leukemia RBL-2H3 cells. J. Exp. Med. 184:71-79.

5. Parravicini, V., M. Gadina, M. Kovarova, S. Odom, C. GonzalezEspinosa, Y. Furumoto, S. Saitoh, L.E. Samelson, J.J. O'Shea, and J. Rivera. 2002. Fyn kinase initiates complementary signals required for IgE-dependent mast cell degranulation. Nat. Immunol. 3:741-748.

6. Hata, D., Y. Kawakami, N. Inagaki, C.S. Lantz, T. Kitamura, W.N. Khan, M. Maeda-Yamamoto, T. Miura, W. Han, S.E. Hartman, et al. 1998. Involvement of Bruton's tyrosine kinase in FceRI-dependent mast cell degranulation and cytokine production. J. Exp. Med. 187:1235-1247.

7. Fukao, T., Y. Terauchi, T. Kadowaki, and S. Koyasu. 2003. Role of phosphoinositide 3-kinase signaling in mast cells: new insights from knockout mouse studies. J. Mol. Med. 81:524-535.

8. Manetz, T.S., C. Gonzalez-Espinosa, R. Arudchandran, S. Xirasagar, V. Tybulewicz, and J. Rivera. 2001. Vav1 regulates phospholipase c $\gamma$ activation and calcium responses in mast cells. Mol. Cell. Biol. 21:3763-3774.

9. Saitoh, S., R. Arudchandran, T.S. Manetz, W. Zhang, C.L. Sommers, P.E. Love, J. Rivera, and L.E. Samelson. 2000. LAT is essential for FceRI-mediated mast cell activation. Immunity. 12:525-535.

10. Zhu, M., Y. Liu, S. Koonpaew, O. Granillo, and W. Zhang. 2004. Positive and negative regulation of FceRI-mediated signaling by the adaptor protein LAB/NTAL. J. Exp. Med. 200:991-1000.

11. Volna, P., P. Lebduska, L. Draberova, S. Simova, P. Heneberg, M. Boubelik, V. Bugajev, B. Malissen, B.S. Wilson, V. Horejsi, et al. 2004. Negative regulation of mast cell signaling and function by the adaptor LAB/NTAL. J. Exp. Med. 200:1001-1013.

12. Pivniouk, V.I., T.R. Martin, J.M. Lu-Kuo, H.R. Katz, H.C. Oettgen, and R.S. Geha. 1999. SLP-76 deficiency impairs signaling via the highaffinity IgE receptor in mast cells. J. Clin. Invest. 103:1737-1743.

13. Wu, J.N., M.S. Jordan, M.A. Silverman, E.J. Peterson, and G.A. Koretzky. 2004. Differential requirement for adapter proteins Src homology 2 domain-containing leukocyte phosphoprotein of $76 \mathrm{kDa}$ and adhesion- and degranulation-promoting adapter protein in FceRI signaling and mast cell function. J. Immunol. 172:6768-6774.
14. Gu, H., K. Saito, L.D. Klaman, J. Shen, T. Fleming, Y. Wang, J.C. Pratt, G. Lin, B. Lim, J.-P. Kinet, and B.G. Neel. 2001. Essential role for Gab2 in the allergic response. Nature. 412:186-190.

15. Schneider, H., A. Cohen-Dayag, and I. Pecht. 1992. Tyrosine phosphorylation of phospholipase C gamma 1 couples the Fc $\varepsilon$ receptor mediated signal to mast cells secretion. Int. Immunol. 4:447-453.

16. Atkinson, T.P., M.A. Kaliner, and R.J. Hohman. 1992. Phospholipase C- $\gamma 1$ is translocated to the membrane of rat basophilic leukemia cells in response to aggregation of IgE receptors. J. Immunol. 148:2194-2200.

17. Liu, Y., C. Graham, V. Parravicini, M.J. Brown, J. Rivera, and S. Shaw. 2001. Protein kinase C $\theta$ is expressed in mast cells and is functionally involved in Fce receptor I signaling. J. Lenkoc. Biol. 69:831-840.

18. Ozawa, K., Z. Szallasi, M. Kazanietz, P. Blumberg, H. Mischak, J. Mushinski, and M. Beaven. 1993. $\mathrm{Ca}(2+)$-dependent and $\mathrm{Ca}(2+)-$ independent isozymes of protein kinase $\mathrm{C}$ mediate exocytosis in antigenstimulated rat basophilic RBL-2H3 cells. Reconstitution of secretory responses with $\mathrm{Ca} 2+$ and purified isozymes in washed permeabilized cells. J. Biol. Chem. 268:1749-1756.

19. Kimata, M., N. Inagaki, T. Kato, T. Miura, I. Serizawa, and H. Nagai. 2000. Roles of mitogen-activated protein kinase pathways for mediator release from human cultured mast cells. Biochem. Pharmacol. 60:589-594.

20. Kazanietz, M.G. 2002. Novel "nonkinase" phorbol ester receptors: the C1 domain connection. Mol. Pharmacol. 61:759-767.

21. Kim, T.D., G.T. Eddlestone, S.F. Mahmoud, J. Kuchtey, and C. Fewtrell. 1997. Correlating Ca2+ responses and secretion in individual RBL-2H3 mucosal mast cells. J. Biol. Chem. 272:31225-31229.

22. Nechushtan, H., M. Leitges, C. Cohen, G. Kay, and E. Razin. 2000. Inhibition of degranulation and interleukin-6 production in mast cells derived from mice deficient in protein kinase C $\beta$. Blood. 95:1752-1757.

23. Zhang, C., N. Hirasawa, and M.A. Beaven. 1997. Antigen activation of mitogen-activated protein kinase in mast cells through protein kinase C-dependent and independent pathways. J. Immunol. 158:4968-4975.

24. Lorentz, A., I. Klopp, T. Gebhardt, M.P. Manns, and S.C. Bischoff. 2003. Role of activator protein 1 , nuclear factor- $\mathrm{\kappa B}$, and nuclear factor of activated $\mathrm{T}$ cells in IgE receptor-mediated cytokine expression in mature human mast cells. J. Allergy Clin. Immunol. 111:1062-1068.

25. Turner, H., and D.A. Cantrell. 1997. Distinct Ras effector pathways are involved in Fce R1 regulation of the transcriptional activity of Elk-1 and NFAT in mast cells. J. Exp. Med. 185:43-54.

26. Wolfe, P.C., E.Y. Chang, J. Rivera, and C. Fewtrell. 1996. Differential effects of the protein kinase $\mathrm{C}$ activator phorbol 12-myristate 13-acetate on calcium responses and secretion in adherent and suspended RBL2H3 mucosal mast cells. J. Biol. Chem. 271:6658-6665.

27. Koopmann, W.R., Jr., and R.C. Jackson. 1990. Calcium- and guanine-nucleotide-dependent exocytosis in permeabilized rat mast cells. Modulation by protein kinase C. Biochem. J. 265:365-373.

28. Wang, D., J. Feng, R. Wen, J.C. Marine, M.Y. Sangster, E. Parganas, A. Hoffmeyer, C.W. Jackson, J.L. Cleveland, P.J. Murray, and J.N. Ihle. 2000. Phospholipase $\mathrm{C} \gamma 2$ is essential in the functions of $\mathrm{B}$ cell and several $\mathrm{Fc}$ receptors. Immunity. 13:25-35.

29. Wen, R., S.-T. Jou, Y. Chen, A. Hoffmeyer, and D. Wang. 2002. Phospholipase $C \gamma 2$ is essential for specific functions of FceR and Fc $\gamma$ R. J. Immunol. 169:6743-6752.

30. Chang, E.Y., Z. Szallasi, P. Acs, V. Raizada, P.C. Wolfe, C. Fewtrell, P.M. Blumberg, and J. Rivera. 1997. Functional effects of overexpression of protein kinase $\mathrm{C}-\alpha,-\beta,-\delta,-\varepsilon$, and $-\eta$ in the mast cell line RBL2H3. J. Immunol. 159:2624-2632.

31. Leitges, M., K. Gimborn, W. Elis, J. Kalesnikoff, M.R. Hughes, G. Krystal, and M. Huber. 2002. Protein kinase C- $\delta$ is a negative regulator of antigen-induced mast cell degranulation. Mol. Cell. Biol. 22:3970-3980.

32. Topham, M.K., and S.M. Prescott. 1999. Mammalian diacylglycerol kinases, a family of lipid kinases with signaling functions. J. Biol. Chem. 274:11447-11450.

33. van Blitterswijk, W.J., and B. Houssa. 2000. Properties and functions of diacylglycerol kinases. Cell. Signal. 12:595-605.

34. English, D., Y. Cui, and R.A. Siddiqui. 1996. Messenger functions of phosphatidic acid. Chem. Phys. Lipids. 80:117-132. 
35. Jones, G.A., and G. Carpenter. 1993. The regulation of phospholipase C- $\gamma 1$ by phosphatidic acid. Assessment of kinetic parameters. J. Biol. Chem. 268:20845-20850.

36. Jenkins, G.H., P.L. Fisette, and R.A. Anderson. 1994. Type I phosphatidylinositol 4-phosphate 5-kinase isoforms are specifically stimulated by phosphatidic acid. J. Biol. Chem. 269:11547-11554.

37. Luo, B., S.M. Prescott, and M.K. Topham. 2004. Diacylglycerol kinase $\zeta$ regulates phosphatidylinositol 4-phosphate 5-kinase I $\alpha$ by a novel mechanism. Cell. Signal. 16:891-897.

38. Zhong, X.P., E.A. Hainey, B.A. Olenchock, H. Zhao, M.K. Topham, and G.A. Koretzky. 2002. Regulation of T cell receptor-induced activation of the Ras-ERK pathway by diacylglycerol kinase $\zeta$. J. Biol. Chem. 277:31089-31098.

39. Zhong, X.P., E.A. Hainey, B.A. Olenchock, M.S. Jordan, J.S. Maltzman, K.E. Nichols, H. Shen, and G.A. Koretzky. 2003. Enhanced T cell responses due to diacylglycerol kinase $\zeta$ deficiency. Nat. Immunol. 4:882-890.

40. Kalesnikoff, J., M. Huber, V. Lam, J.E. Damen, J. Zhang, R.P. Siraganian, and G. Krystal. 2001. Monomeric IgE stimulates signaling pathways in mast cells that lead to cytokine production and cell survival. Immunity. 14:801-811.

41. Kitaura, J., K. Asai, M. Maeda-Yamamoto, Y. Kawakami, U. Kikkawa, and T. Kawakami. 2000. Akt-dependent cytokine production in mast cells. J. Exp. Med. 192:729-740.

42. Jabril-Cuenod, B., C. Zhang, A.M. Scharenberg, R. Paolini, R. Numerof, M.A. Beaven, and J.P. Kinet. 1996. Syk-dependent phosphorylation of Shc. A potential link between FceRI and the Ras/mitogen-activated protein kinase signaling pathway through SOS and Grb2. J. Biol. Chem. 271:16268-16272.

43. Turner, H., K. Reif, J. Rivera, and D.A. Cantrell. 1995. Regulation of the adapter molecule Grb2 by the FceR1 in the mast cell line RBL2H3. J. Biol. Chem. 270:9500-9506.

44. Li, L., Y. Yang, and R.L. Stevens. 2003. RasGRP4 regulates the expression of prostaglandin D2 in human and rat mast cell lines. J. Biol. Chem. 278:4725-4729.

45. Li, L., Y. Yang, G.W. Wong, and R.L. Stevens. 2003. Mast cells in airway hyporesponsive $\mathrm{C} 3 \mathrm{H} / \mathrm{HeJ}$ mice express a unique isoform of the signaling protein $\mathrm{R}$ as guanine nucleotide releasing potein 4 that is unresponsive to diacylglycerol and phorbol esters. J. Immunol. 171:390-397.

46. Yang, Y., L. Li, G.W. Wong, S.A. Krilis, M.S. Madhusudhan, A. Sali, and R.L. Stevens. 2002. RasGRP4, a new mast cell-restricted Ras guanine nucleotide-releasing protein with calcium- and diacylglycerolbinding motifs. J. Biol. Chem. 277:25756-25774.

47. Leitges, M., K. Gimborn, W. Elis, J. Kalesnikoff, M.R. Hughes, G. Krystal, and M. Huber. 2002. Protein kinase C- $\delta$ is a negative regulator of antigen-induced mast cell degranulation. Mol. Cell. Biol. 22:3970-3980.

48. Sekiya, F., Y.S. Bae, and S.G. Rhee. 1999. Regulation of phospholipase C isozymes: activation of phospholipase $\mathrm{C}-\gamma$ in the absence of tyrosinephosphorylation. Chem. Phys. Lipids. 98:3-11.

49. Kawakami, T., and J. Kitaura. 2005. Mast cell survival and activation by $\operatorname{IgE}$ in the absence of antigen: a consideration of the biologic mechanisms and relevance. J. Immunol. 175:4167-4173.

50. Asai, K., J. Kitaura, Y. Kawakami, N. Yamagata, M. Tsai, D.P. Carbone, F.T. Liu, S.J. Galli, and T. Kawakami. 2001. Regulation of mast cell survival by IgE. Immunity. 14:791-800.

51. Kawakami, T., and S.J. Galli. 2002. Regulation of mast-cell and basophil function and survival by IgE. Nat. Rev. Immunol. 2:773-786.

52. Xiang, Z., A.A. Ahmed, C. Moller, K. Nakayama, S. Hatakeyama, and G. Nilsson. 2001. Essential role of the prosurvival bcl-2 homologue A1 in mast cell survival after allergic activation. J. Exp. Med. 194:1561-1569.

53. Lantz, C.S., J. Boesiger, C.H. Song, N. Mach, T. Kobayashi, R.C. Mulligan, Y. Nawa, G. Dranoff, and S.J. Galli. 1998. Role for interleukin-3 in mast-cell and basophil development and in immunity to parasites. Nature. 392:90-93

54. Kirshenbaum, A.S., J.P. Goff, S.C. Dreskin, A.M. Irani, L.B. Schwartz, and D.D. Metcalfe. 1989. IL-3-dependent growth of basophil-like cells and mastlike cells from human bone marrow. J. Immunol. 142 2424-2429.

55. Chaikin, E., H.J. Ziltener, and E. Razin. 1990. Protein kinase C plays an inhibitory role in interleukin 3- and interleukin 4-mediated mast cell proliferation. J. Biol. Chem. 265:22109-22116.

56. Gold, M.R., V. Duronio, S.P. Saxena, J.W. Schrader, and R. Aebersold. 1994. Multiple cytokines activate phosphatidylinositol 3-kinase in hemopoietic cells. Association of the enzyme with various tyrosine-phosphorylated proteins. J. Biol. Chem. 269:5403-5412.

57. Park, D.J., H.K. Min, and S.G. Rhee. 1992. Inhibition of CD3-linked phospholipase $\mathrm{C}$ by phorbol ester and by cAMP is associated with decreased phosphotyrosine and increased phosphoserine contents of PLC- $\gamma$ 1. J. Biol. Chem. 267:1496-1501.

58. Ryu, S.H., U.H. Kim, M.I. Wahl, A.B. Brown, G. Carpenter, K.P. Huang, and S.G. Rhee. 1990. Feedback regulation of phospholipase C- $\beta$ by protein kinase C. J. Biol. Chem. 265:17941-17945.

59. Ozawa, K., K. Yamada, M.G. Kazanietz, P.M. Blumberg, and M.A. Beaven. 1993. Different isozymes of protein kinase C mediate feedback inhibition of phospholipase $\mathrm{C}$ and stimulatory signals for exocytosis in rat RBL-2H3 cells. J. Biol. Chem. 268:2280-2283.

60. Kang, S.W., M.I. Wahl, J. Chu, J. Kitaura, Y. Kawakami, R.M Kato, R. Tabuchi, A. Tarakhovsky, T. Kawakami, C.W. Turck, et al 2001. PKC $\beta$ modulates antigen receptor signaling via regulation of Btk membrane localization. EMBO J. 20:5692-5702.

61. Kawakami, Y., J. Kitaura, D. Hata, L. Yao, and T. Kawakami. 1999. Functions of Bruton's tyrosine kinase in mast and B cells. J. Leukoc. Biol. 65:286-290.

62. Matsuda, S., Y. Miwa, Y. Hirata, A. Minowa, J. Tanaka, E. Nishida, and S. Koyasu. 2004. Negative feedback loop in T-cell activation through MAPK-catalyzed threonine phosphorylation of LAT. EMBOJ. 23:2577-2585.

63. English, D. 1996. Phosphatidic acid: a lipid messenger involved in intracellular and extracellular signalling. Cell. Signal. 8:341-347.

64. Choi, W.S., Y.M. Kim, C. Combs, M.A. Frohman, and M.A. Beaven. 2002. Phospholipases D1 and D2 regulate different phases of exocytosis in mast cells. J. Immunol. 168:5682-5689.

65. Cockcroft, S., G. Way, N. O'Luanaigh, R. Pardo, E. Sarri, and A. Fensome. 2002. Signalling role for ARF and phospholipase D in mast cell exocytosis stimulated by crosslinking of the high affinity FceR 1 receptor. Mol. Immunol. 38:1277-1282.

66. Saito, K., K.F. Tolias, A. Saci, H.B. Koon, L.A. Humphries, A. Scharenberg, D.J. Rawlings, J.P. Kinet, and C.L. Carpenter. 2003. BTK regulates PtdIns-4,5-P2 synthesis: importance for calcium signaling and PI3K activity. Immunity. 19:669-678.

67. Oancea, E., and T. Meyer. 1998. Protein kinase C as a molecular machine for decoding calcium and diacylglycerol signals. Cell. 95:307-318.

68. Gronert, K., A. Kantarci, B.D. Levy, C.B. Clish, S. Odparlik, H Hasturk, J.A. Badwey, S.P. Colgan, T.E. Van Dyke, and C.N. Serhan. 2004. A molecular defect in intracellular lipid signaling in human neutrophils in localized aggressive periodontal tissue damage. J. Immunol. 172:1856-1861.

69. Lauener, R., Y. Shen, V. Duronio, and H. Salari. 1995. Selective inhibition of phosphatidylinositol 3-kinase by phosphatidic acid and related lipids. Biochem. Biophys. Res. Commun. 215:8-14.

70. Karasuyama, H., and F. Melchers. 1988. Establishment of mouse cell lines which constitutively secrete large quantities of interleukin 2,3 , 4 or 5 , using modified cDNA expression vectors. Eur. J. Immunol. 18:97-104.

71. Bunting, M., W. Tang, G.A. Zimmerman, T.M. McIntyre, and S.M. Prescott. 1996. Molecular cloning and characterization of a novel human diacylglycerol kinase $\zeta$. J. Biol. Chem. 271:10230-10236.

72. Peng, Z., and M.A. Beaven. 2005. An essential role for phospholipase $\mathrm{D}$ in the activation of protein kinase $\mathrm{C}$ and degranulation in mast cells. J. Immunol. 174:5201-5208.

73. Maekawa, A., K.F. Austen, and Y. Kanaoka. 2002. Targeted gene disruption reveals the role of cysteinyl leukotriene 1 receptor in the enhanced vascular permeability of mice undergoing acute inflammatory responses. J. Biol. Chem. 277:20820-20824. 